\title{
Fourth Report on the Excavations at Tell Zakarîya; Third Report on the Excavations at Tell es-Sâfi; List of Casts and Moulds
}

\section{F. J. Bliss}

To cite this article: F. J. Bliss (1900) Fourth Report on the Excavations at Tell Zakarîya; Third Report on the Excavations at Tell es-Sâfi; List of Casts and Moulds, Palestine Exploration Quarterly, 32:1, 7-29, DOI: 10.1179/peq.1900.32.1.7

To link to this article: http://dx.doi.org/10.1179/peq.1900.32.1.7

曲 Published online: 20 Nov 2013.

Submit your article to this journal $\pi$

Џ Article views: 14

Q View related articles 5

4 Citing articles: 1 View citing articles $\sqsubset$ 
FOURTH REPORT ON THE EXCAVATIONS AT TELI ZAKARÎYA.

\author{
By F. J. Buiss, Ph.D.
}

ON resuming work at this site on September 11th I was fully impressed with the situation of affairs. The details of the fortress had been fully worked out, and no other important building had been found. Accordingly nothing remained for us to do but to put in practice the theory which I stated on p. 23 of the January Quarterly Statement for the current year:"After several years of digging in Palestine I have come to the conelusion that, owing to many conditions that need not be detailed now, antiquities are exceedingly scarce, and that the only hope for finding these is, first, to choose a site that is proved to be ancient, and then to turn over great quantities of soil on that site." Now the antiquity of Tell Zakarîya had been amply proved by the objects found. Not to go into details, it seemed indisputable that we had found traces both of pre-Israelite and Jewish occupations. The lower stratum showed scarabs of the eighteenth dynasty and types of pottery of the same date, similar to those found in the stratum at Tell el-Hesy, which contained the cuneiform tablet. In the upper stratum had been found jar-handles and weights, inscribed in Hebrew, presumably of the time of the Hebrew monarchy. The reasons for turning over about half the soil in the interior of the fortress had been two: First, to determine the nature and number of periods of the structures within; and, second, if possible, to discover important inscriptions. The results of the first quest are shown in the plans and sections published in the July Quarterly. The results of the second were disappointing, for while the short inscriptions referred to above turned up, no important steles were found. Accordingly it seemed best to turn our attention to the lower plateau. A series of 16 pits sunk on this plateau during our first season had revealed a depth of soil ranging from 6 to 18 feet, which showed two strata: the lower, pre-Israelite; the upper, Jewish. Our main, 
if not our chief, hope in beginning a large clearance was for cuneiform tablets in the lower stratum, tablets that might throw further light on the history of the land before the Jewish Conquest, and give us the other end of the Tell el-Amarna correspondence; and for Hebrew steles in the upper stratum which might have the interest attaching to the Moabite Stone, or to the Siloam Inscription. Incidentally we hoped to add to our knowledge of the pottery. In reporting that while this last. hope was fulfilled the others were doomed to disappointment, I must not be held to disćredit my theory of digging. Tablets may or may not occur in the unexcavated parts of Tell Zakarîya, but the soil in which we were working is certainly the soil in which tablets may be looked for. Tell el-Hesy is very much smaller than Tell Zakarîya, and Tell el-Hesy had its tablet, and the unexcavated portions may hold many more.

The plan of the plateau is given on the plate facing p. 16 in the January Quarterly Statement. It is in the form of a. rude triangle trending north-eastwards from its base, the road from the valley striking the summit at the apex. The northern part of the plateau is fairly level, and has a distinct edge. On the south-eastern portion are superimposed the ruins of the fortress. At the south-west the surface is irregular, and shows an outcrop of rock, in which wine and olive presses have been cut. The most favourable portion for digging appeared to be along the line $\mathrm{CD}$, in the centre of which had been found a quantity of early pottery. This point was taken as the centre of a large clearance to the rock, 80 feet by 60 feet, worked in sections each 30 feet broad, according to the method described before. ${ }^{1}$ The rock lies at an average depth of about 14 feet. A third section, of the same dimensions, was begun, but deepened for 7 feet only, this depth representing the stratum in which Jewish inscriptions might be expected.

Immediately under the surface we found many walls enclosing small rooms. They are built of rubble, and range in breadth from 2 to 4 feet. As the pottery found within these walls was Jewish or earlier, including many whole examples, with no admixture of Roman or Arab, it appears to be proved

1 See p. 98, April Quarterly Statement. 
TELL ZAKARIYYA EXCAVATION

VAT-SYSTEM

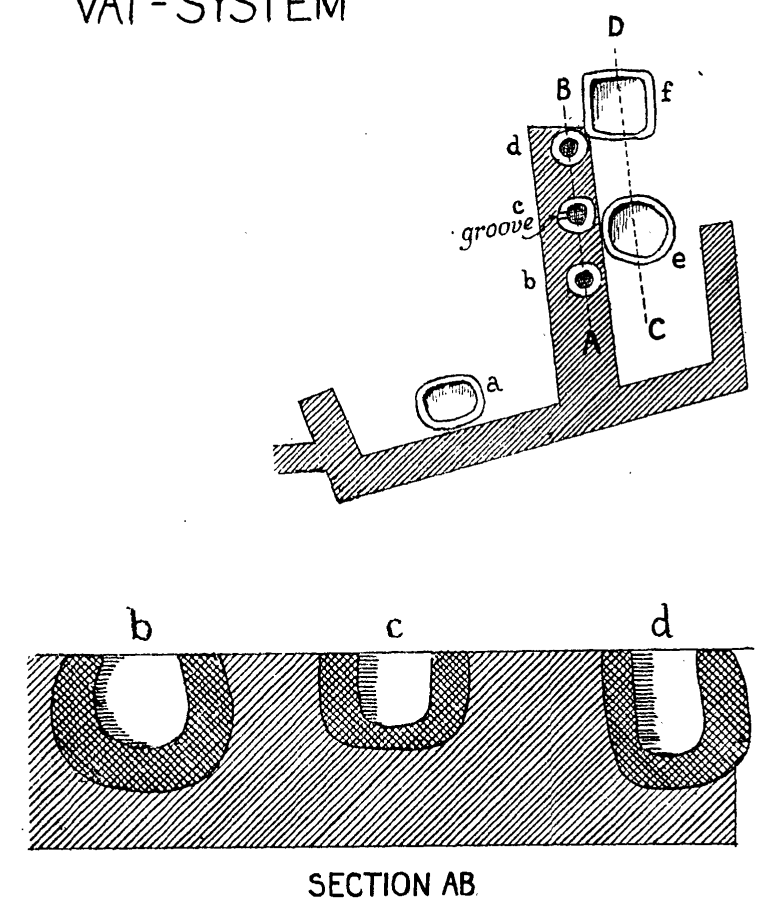

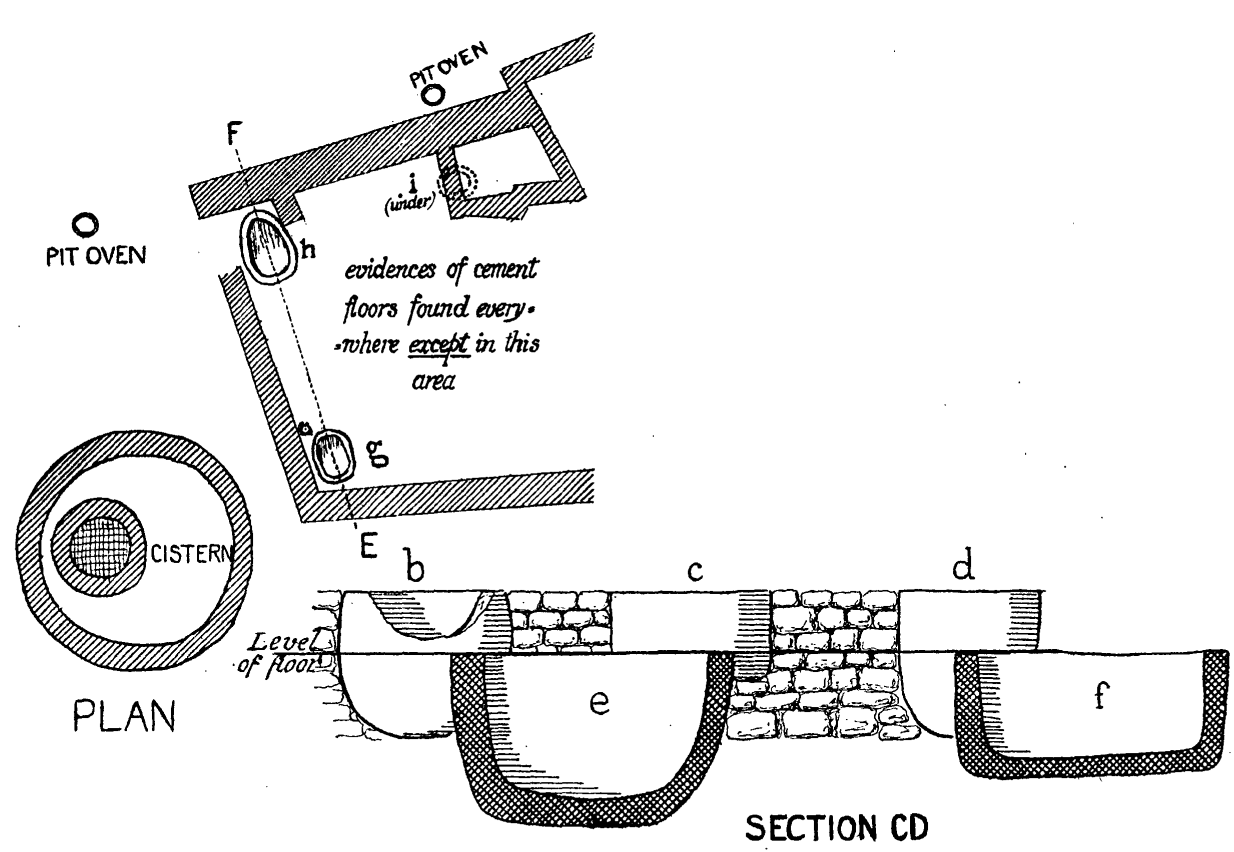
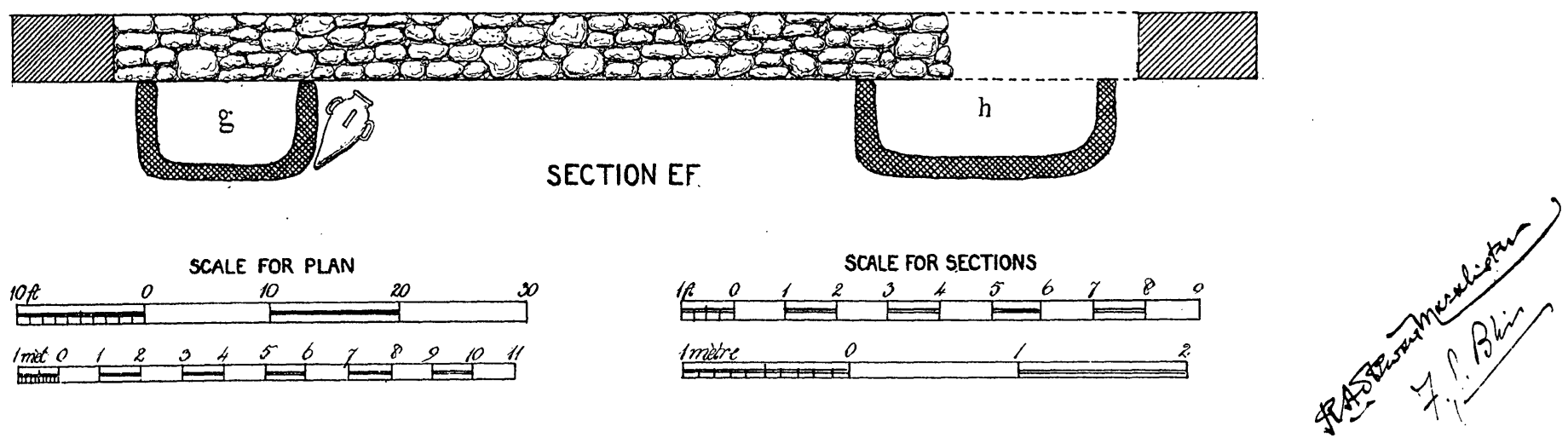

Photo inthographed \& 
that this part of the Tell has not been rebuilt since the Jewish period. The walls stand nowhere for more than 3 feet, and they rest immediately on the debris. They are much ruined, many are in their present condition isolated, and nothing would be gained by publishing a full plan, which without much reconstruction would be unintelligible. We submit, however, a plan of a portion of the remains, which contains a system of stone vats (see Plate I). The three small vats, $b, c$, and $d$, globular in shape, are sunk in a divarf wall 3 feet high. One foot below its top there is a cement flooring, flush with the rims of the vats $e$ and $f$, as seen on section line CI). There is no direct means of connection between the higher and the lower system, and the liquid (wine, oil, or treacle) must have been transferred manually from the vats in the wall to the vats in the floor.

In passing a yard at Beit Jibrîn the other day I noticed a system of vats not unlike those just described. A man and wife were scooping out oil just pressed from the olives, and pouring it into another. The internal depths of vats $b, c$, and $d$ are 18, 15, and 22 inches respectively; the diameters at the mouth are 14,14, and 12 inches respectively; all-over diameters across top, 30,31 , and 33 inches. Vat $c$ has a small groove near the top. The two lower vats, $e$ and $f$, are 28 and 18 inches in depth respectively; diameters at mouth, 44 and 49 inches; thickness of sides, 4 to 6 inches. Vat a probably belongs to this same system.

Vats $g$ and $h$ were sunk below the level of the flooring, and their tops are flush with the base of the adjacent wall. The flooring, however, is ruined, though traces of it remain immediately along the line of the wall. The large jar with four handles, near vat $g$, appears to be a foundation deposit. The measurements of vats $g$ and $h$ are as follows :-Depths, 19 and 21 inches respectively ; thickness of sides, 4 to 6 inches; large internal axis, 36 and 48 inches. Vat $i$ lies under one of several dwarf walls, only 1 foot high, which divide a plaster floor into compartments, probably used as vats. Vat $i$ is, of course, earlier than the compartments. It is 16 inches deep, and 18 inches across the mouth. The bottom was broken out, and 
has been repaired with a fine white cement. On its surface signs of pock-dressing appear.

The cistern shown on the plan consists of a natural cavern, with a shaft built up to the present surface in two rings of rude masonry, not concentric, with a rough filling in between them. The top was covered over with large slabs immediately under the surface, though the existence of the shaft did not seem to be known to the Fellahîn.

In the lower or pre-Israelite stratum was found another series of very rude constructions, too ruined to form a coherent plan. Signs of two periods were observed; for example, a circular brick construction had been broken into by the foundations of a later wall. This resembled a large pit-oven, but, as the usual signs of burning on the interior surface were absent, it must have served some other purpose. Its over-all diameter was about 4 feet, the walls being 7 inches thick, consisting of sun-dried bricks, white with red facing, both inside and out. Signs of a small opening appeared about 2 feet from the bottom. On the floor inside was a layer of ashes, containing small fragments of pottery, stones with traces of severe firing, and human bones, also burned, including a radius, a pelvis, a bit of a tibia, and a fragment of a sacrum. That these had not been burned within the construction is proved by the absence of firing on its walls. If similar constructions containing burned bones be found in the future we shall be better able to settle the question whether the bones were deposited on purpose or whether we have here an ordinary receptacle for grain into which bones had been accidentally cast. Another possible explanation occurred to us while the construction was being cleared out. Above the ashes it was filled with débris containing fragments of brick, which appeared to be parts of the ruined walls of the construction itself. Three of these contained circular channels, of about 1 inch diameter, which suggested the tuyerres found in the furnace excavated at Tell el-Hesy (see my "Mound of Many Cities," p. 46), which, however, showed a much larger chamber, having a diameter of 7 feet. The absence of firing in the Tell Zakarîya construction appears to militate against one supposing these channels to be 


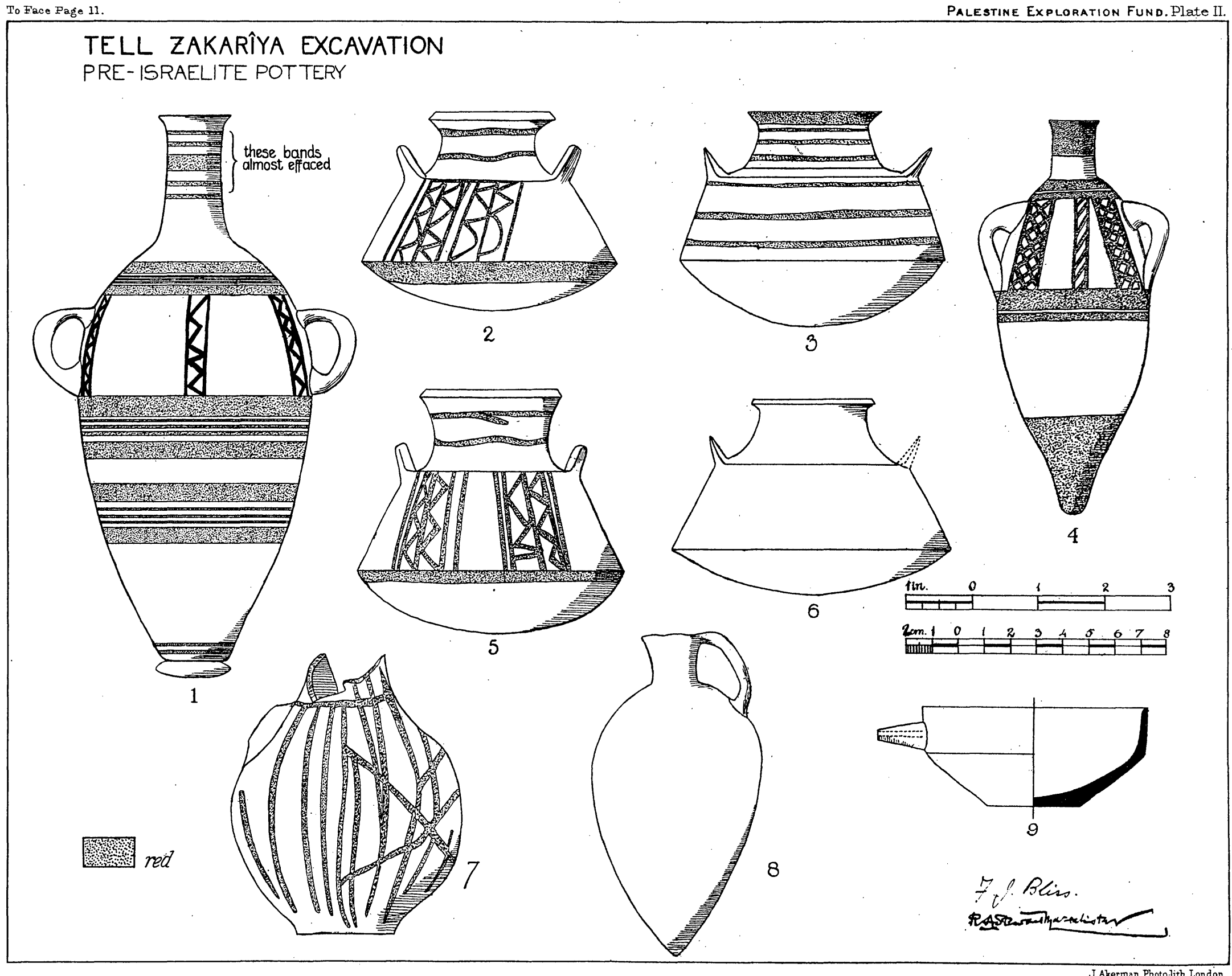


tuyères. No such channels were found in the 3 feet of walling which remains standing. Their purpose remains obscure.

Many whole jars and vases were found in the course of this excavation. Several of these are now published. The types are Jewish and pre-Israelite. It will be well to explain the sense in which we use these terms. As proved by the stratified mound, Tell el-Hesy, where eight superimposed cities were excavated, the pottery of Palestine, before the Seleucidan period, may be conveniently divided into three classes. First, the types called by Petrie "Amorite," showing peculiar characteristics, such as ledge-handles, patterned burnishing, comb-facing, \&c. These occurred in the first, or lowest, city to the exclusion of all other types, but extended in more or less modified forms into Jewish times. Very little of this ware was found at Tell Zakarîya, but Tell es-Sâfi has a stratum on the rock which shows these types to the exclusion of all others. We prefer to call this ware early pre-Israelite rather than Amorite. The second class includes Phoenician ware and local shapes, based upon the Phoenician, together with certain associated types, which are found as early as 1400 B.c., but which also come down to Jewish times. These we name later pre-Israelite. By the time of the later Hebrew monarchy both the "Amorite" and Phoenician types have degenerated, and we find a class of pottery showing a mixture of styles. Hence, in using the term pre-Israelite in regard to any given jar we mean that it belongs to a type that came in during pre-Israelite times, though the particular specimen may have been made during the early Hebrew monarchy. On the contrary, in using the term Jewish we exclude not only pre-Israelite times, but also the period of the early Jewish monarchy. In speaking of strata, however, where we have thousands of specimens to consider, as well as associated objects which may be dated, the use of the terms is fairly inclusive: in other words, the two strata may be taken to represent an accumulation extending from pre-Israelite to late Jewish times.

On Plate II are shown some pre-Israelite types. No. 1 is of fine drab-coloured paste, ornamented in black and red. The line and zigzag pattern is characteristic. It is $27 \cdot 75$ centimetres 
in height, the body is oval, it has a slightly convex disc base, two loop handles, and long cylindrical neck, slightly expanding at the mouth. No. 4 is of the same general type, but it is smaller and the ornamentation is different. The vessels 2,3 , 5 , and 6 , are of one type, having convex bases, wide mouths, and small ear handles. They all show painted ornament except No. 6 . No. 8 is a jug with the characteristic pointed Phoenician base. Nos. 7 and 9 are uncharacteristic, but being found near the rock are placed on this plate. On Plate III a mark of query is put after the title "Jewish" as some of the forms are uncertain. Nos. 3 and 6 are clearly late. Nos. 1 and 2 were found on the dividing line between the two strata; they have the painted bands characteristic of the earlier ware, but their clumsy shapes suggest the time when degeneration had set in. They both spring from a trumpet-shaped hollow foot, as shown in section. No. 1 has a cylindrical neck with roll-moulded mouth. The neck of No. 2 is very short, producing an unsymmetrical effect. No. 5 was found near the surface and is of a type new to us. It is a small jug with. very thick side, and having a long, heavily-moulded neck, all out of proportion to the size of the vessel. The handle is broken off. No. 4 is of the Pilgrim-bottle type.

Four jar-handles with Royal stamps were found. The first shows the four-winged symbol, with the inscription שובה, similar to those previously published. The second is interesting from the fact that the body of the four-winged creature is found for the first time with pronounced articulations. One possible objection suggested by Mr. Macalister to the proposed identification of the symbol with the flying scarabæus beetle is the outward curvature of what would, according to this theory, represent the elytra or hard wing cases, which is exactly the reverse of the natural curvature. A facsimile drawing is submitted. The place-name is greatly worn, but the first letter is clearly ; the last is probably פ, and the long bar of the ' appears in the middle letter. Mr. Macalister also recognises traces of the crossbars as dotted in on the cut. This gives זיף (Ziph) (Cut I) for the reading. The name of this city is probably found on Example No. 9, Plate V, July 


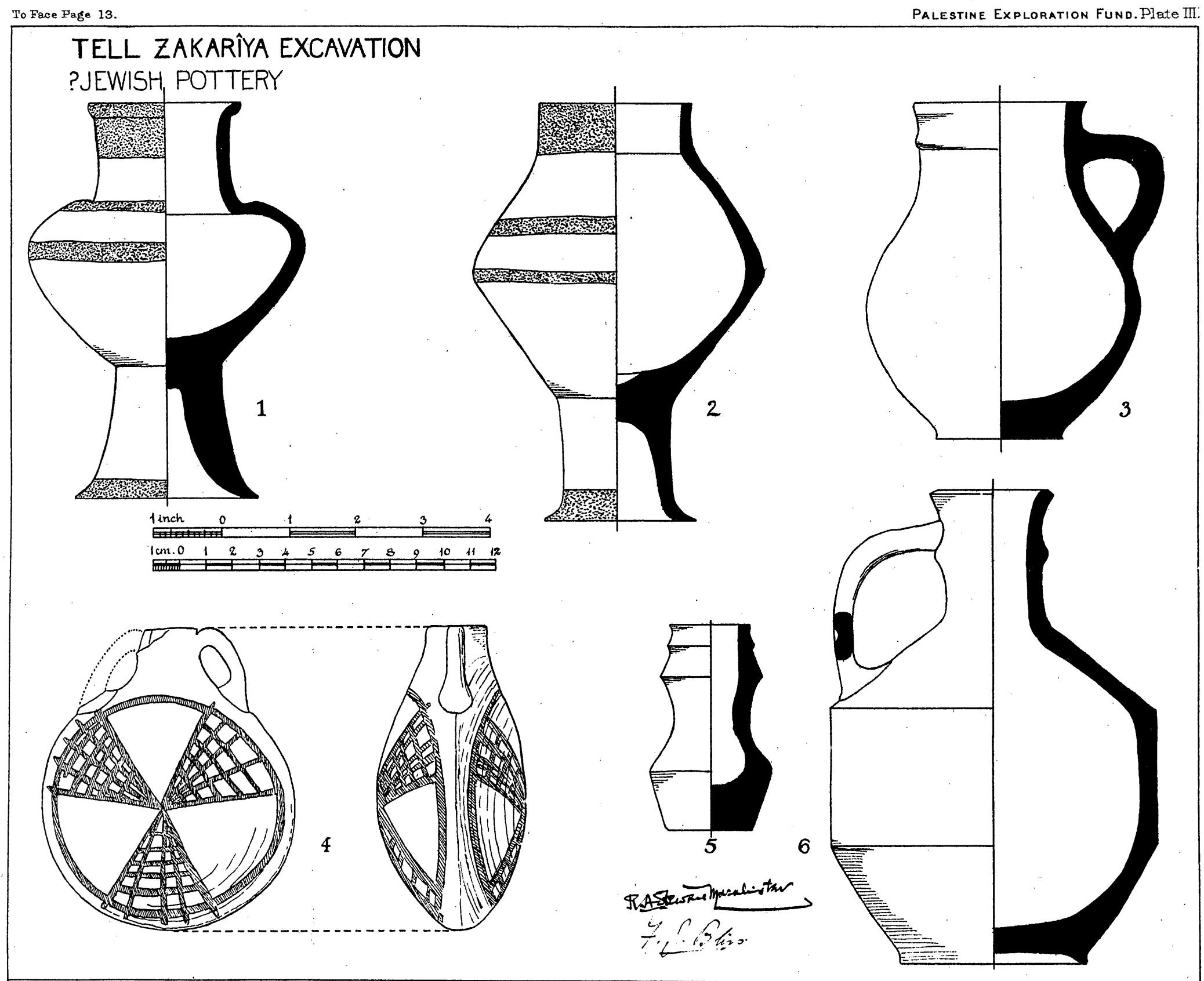

J.Akerman, Photo-lith. Lond on 
Quarterly Statement. The third was imperfectly stamped, and shows only the lower half of the oval, but the figure was clearly of the four-winged type; the place-name is probably Hebrew, as the first two letters, $\pi$ and $\beth$, are clear. Of the other letters no traces remain. The fourth specimen shows the symbol of the two-winged type; it is so badly distintegrated that even the symbol is faint, and not a sign of lettering remains in either line.

In the upper, or late Jewish, stratum, only 2 feet under the surface, was found a jar-handle of dark red ware, with a pronounced rib in the centre, above which is the impression of a seal. The stamp is enclosed in an ellipse (see. No. 1 in Cut II, p. 18), and is divided into two parts by a horizontal line separating

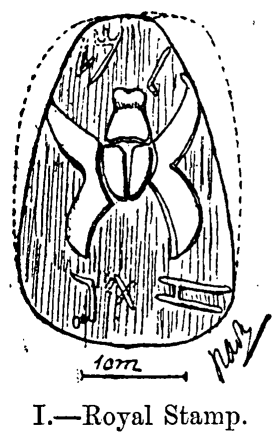

two lines of writing. The letters were coarsely cut on the seal. The four letters forming the upper line are perfectly clear, and read לעי The large size of the 'ayin and its oval shape are to be remarked. In the lower line the first letter is plainly cheth and the last yod. The main vertical line of the central letter is clear, but the top part is somewhat obscure, and at first we were doubtful whether it were a vau or resh. In the first case we must read חוי, in the second דרי . Careful microscopic examination, however, revealed the salient features of the resh. Accordingly we have for the reading of the stamp: " Belonging to 'Ezer, 'Hori." 'Ezer is found as a proper name in Num. xiii, 5, 1 Chron. xii, 9, and Neh. xii, 42 ; in the first reference we find mention of 'Hori, son of Shaphat, of the tribe 
of Judah. The absence of the article in the stamp seems to forbid our reading the word as Horite, for with this meaning the article is indispensable. This fact strengthens the case against as there is no example where this word is used as the name of an individual; it is always employed generically, החוי , i.e., the Hivite.

Stamp No. 2 (p. 18) was not found on the plateau but near the edge of our large clearance pit inside the fortress, which was abandoned last spring. The letters are exceedingly fine, and the jar-handle was probably overlooked by our workmen, who may have taken it for a mere finger-print, which is a common feature on jar-handles. I may mention incidentally that in case we find that anything important has been overlooked, such visions of lost bakhsheesh are presented to the workmen that anything bearing the slightest resemblance to the recovered object is subsequently treasured up for our inspection. One compensation for having to fill up the excavations is the fact that the soil has to be re-handled. I am glad to say that the increasing care of the workmen is proved by the lack of finds in the course of our latest filling up. This jar-handle is of red ware, similar to No. 1, but has two pronounced ribs. The stamp is elliptical in form, the two lines of writing being separated by two parallel bars like the example figured on p. 198 of the July Quarterly. In stamping the pressure was unequally applied, so that the lower right corner of the ellipse does not appear. The upper line reads לצפביז Owing to a small cavity in the surface the lower end of the $\square$ is not traceable. Between the last two letters occurs a short vertical mark, which does not extend to a second small imperfection found below it. That this mark is not accidental is indicated by the following considerations:-(1) The relief is precisely similar in character to the relief of the letters. (2) If we ignore it, the distance between the last two letters appears to be a trifle too great. (3) Similar marks may be seen in examples 7 and 9 of the stamped jar-handles figured on Plate $\mathrm{V}$ facing p. 184 of the July Quarterly. The lower line reads מעy, but these letters do not occupy the centre of the line, place for one letter remaining before the $\mathbf{2}$. Now this word; signifying 


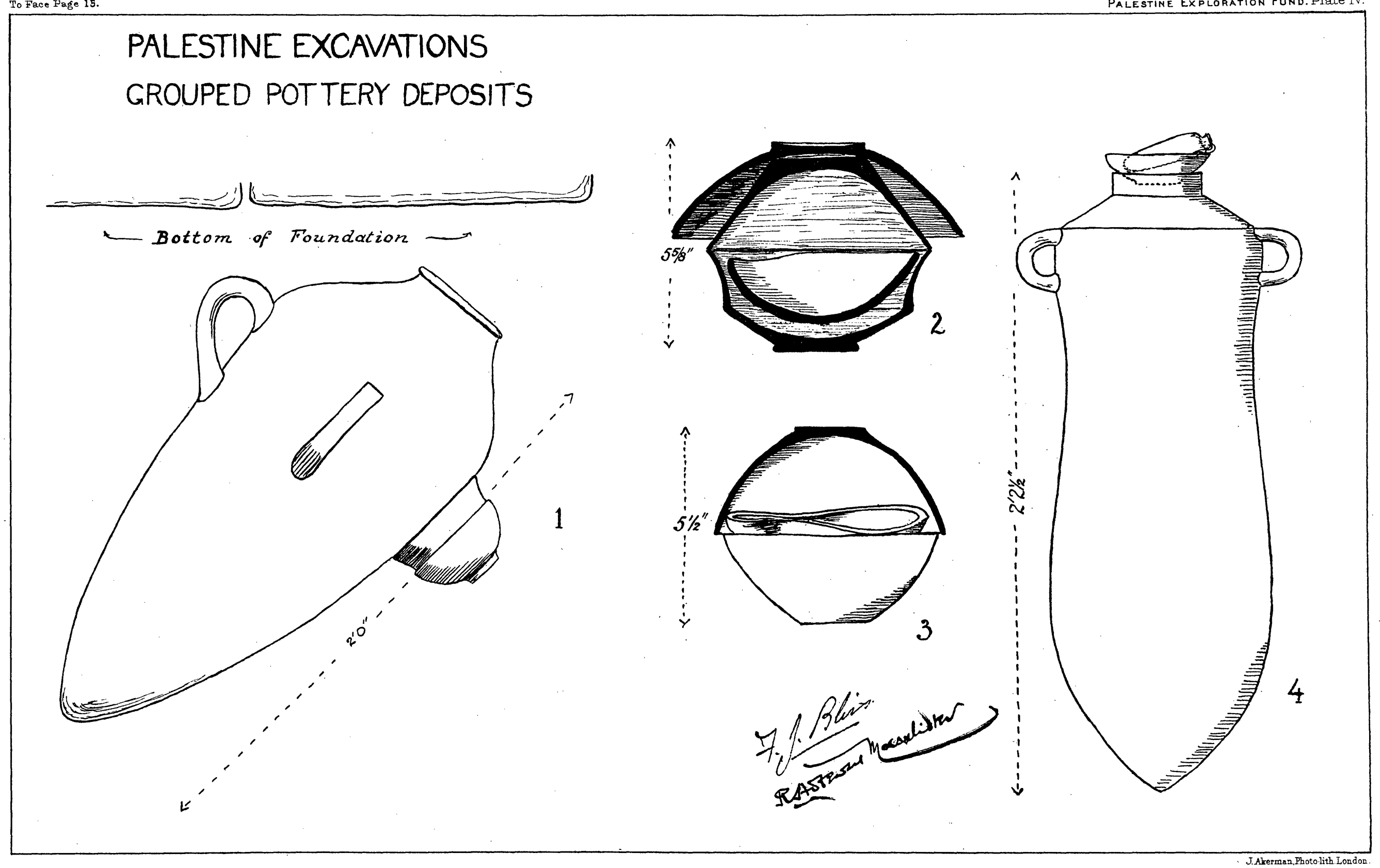


anger, is found as a personal name in 1 Chron. ii; 27. The quadrilateral צפנפ, however, presents difficulties. The root [צ्S occurs in the personal name צפביה-Zephanîah, which signifies "Jehovah protects." . As a possible solution; I would propose to restore a letter in the vacant space before the $\boldsymbol{D}$, to regard the small vertical mark between the last two letters of the first line as a mark of separation between two words, and thus to read לצפן א-מעית. In the case of the Royal stamps, mentioned above, this vertical mark seems to serve the purpose of a hyphen between two parts of the same word separated by the symbol, whereas in the present case we assume it to be equivalent to the modern printer's dash. Possibly the lost letter may be a $ב$, in which case we would have the word "the father of wrath," a name analogous to (Ahimaaz), "the brother of wrath" (see 1 Sam. xiv, 50). As neither nor occur in Scripture, our suggestions are offered with considerable hesitation.

Stamp No. 3 (p. 18) was found at Tell es-Sâf. The oval is divided into three parts by two vertical lines. In the central division we have seven symbols. At the bottorn are two identical symbols side by side; these two are also found at the top but reversed in position. The three symbols found between these two pairs appear twice repeated in the right division of the oval. The left division is much - worn, but signs of a similar double repetition appear, the symbols, however, being inverted and the order changed. Three of the symbols found on this stamp appear on Scarab No. 3, Plate VI, in the October Quarterly.

On Plate IV are shown various groups of pottery deposits. Nos. 1 and 2 are from Tell Zakarîya, the rest from Tell esSâfi. Nos. 2 and 3 are the most common. In group No. 2 we have four vessels: A bowl containing a lamp, filled with fine earth, covered by a second bowl, inverted, above which is another inverted bowl. Where the vessels do not fit closely the intervening spaces are also filled with fine earth. No. 3 differs from No. 2 in having but one inverted bowl. These were found buried near the bases of walls. Similar deposits were very common at Tell el-Hesy, in Cities IV and Sub-IV, which 
are dated from about 1400 to 1000 B.c. ${ }^{1} \quad$ The position of group No. 1 with reference to the base of a wall is shown on the plate. Here we have two vessels, first a small bowl (similar to the lowest bowl in group No. 2), somewhat tilted; second, a large jar with four handles, also tilted on its side, so that one handle rests within the bowl. For a somewhat similar combination of jar and bowl, see Plate IV, July Quarterly. " In group No. 4 we have a long cylindrical jar, placed upright on its pointed bottom; the mouth is closed by a bowl, not inverted, on which rests a small jug. The shape of the jar is new to us, but the associated vessels appear to be early Jewish. Another form of jar-burial (obtaining also at Tell el-Hesy) was found at Tell es-Sâfi. A large jar was found resting on its side, the mouth broken away to admit of the insertion of two jugs and a bowl, which were found within. It was packed with fine earth and contained small bones, apparently of birds. The report from Tell es-Sâfi will refer to a jar-burial antedating the examples just mentioned.

Tell eJ.Judeideh, December 4th, 1899.

\section{THIRD REPORT ON THE EXCAVATIONS AT TELL ES-SÂFI.}

By F. J. Bliss, Phi.D.

The Tell es-Sâfi excavations were resumed October 9th and continued to November 22nd, when preparations were begun for moving camp to Tell ej-Judeideh. During this period an enormous quantity of soil was turned over; but unfortunately with very few results. In my report in the July Quarterly, p. 191, I called attention to the difficulties attending excavations on this site:- " The south end is occupied by the modern graveyard, the modern village rules out the north portion, while another graveyard is found over a great part of the narrow plateau extending to the north-east. We are thus

1 See "Mound of Many Cit'es," p. 84. 
confined to the steep slopes above the wall, to a portion of the north-east plateau, and to a narrow section across the summit, east and west, between the southern graveyard and the modern town. The last portion does not give us a free hand as it is divided into three fields by lofty and dense hedges of cactus, the central field being planted with vegetables. The graveyard at the important south end will, of course, prevent our searching for the ancient Acropolis, but even if the tombs did not exist the earliest remains could not have been examined here without digging through the foundations of BlancheGarde."

We have already reported on the large clearance made on the north-east plateau, where rude walls enclosing three standing stones, perhaps representing the remains of an early place of worship, were found. It seemed best, on our return, to attack a point more within the centre of the town and near to the Acropolis. The crops having been reaped in the western field of the series of three just mentioned as lying between the Wely and the town, we were able in July to sink several shafts to determine the nature and depth of the accumulation. In this field we have since made a large clearance to the rock, 80 feet by 60 feet, and on the average about 16 feet deep. Allowing for the space to deposit the earth, this was about as large an excavation as the field would permit. The pottery showed three strata-Jewish, late pre-Israelite, and early pre-Israelite. The extreme paucity of Arab ware in the upper stratum was curious considering the proximity to BlancheGarde, and the fact that much Arab stuff was found in the neighbouring field. Walls were found at two different levels, in some cases still enclosing small rooms, two of which have doors. The construction is of the rudest, far worse than anything found at the north-east plateau. In fact, the houses appear to be quite as wretched as the hovels of the modern village. Some jars and bowls, the stamped jar-handle No. 3 (Cut II, p. 18), numerous flints, four scarabs, a few ordinary Egyptian amulets, a Babylonian cylinder, and the slate object resembling an eye (see Cut III), but evidently, from the markings on the back, cut out of some larger stele, were 

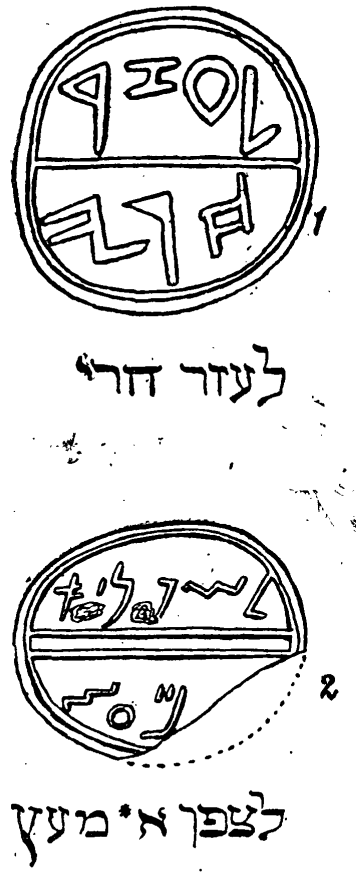

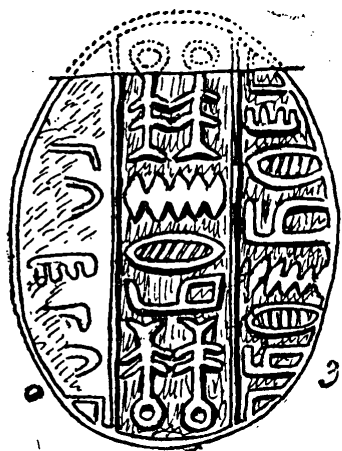

\section{1oentimitre}

II.-Seals impressed upon Jar-handles.
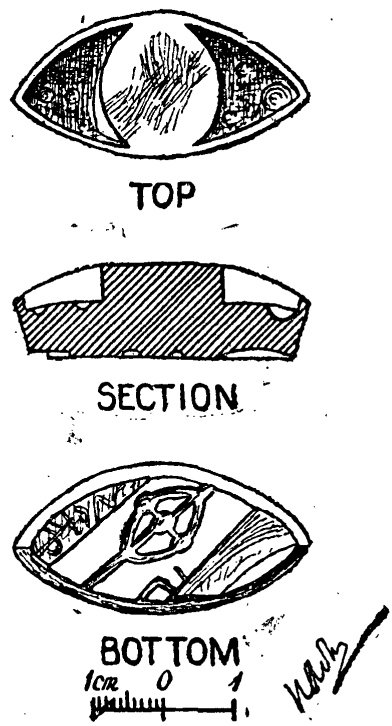

III.-Figure of an Eve, in polished black marble. 

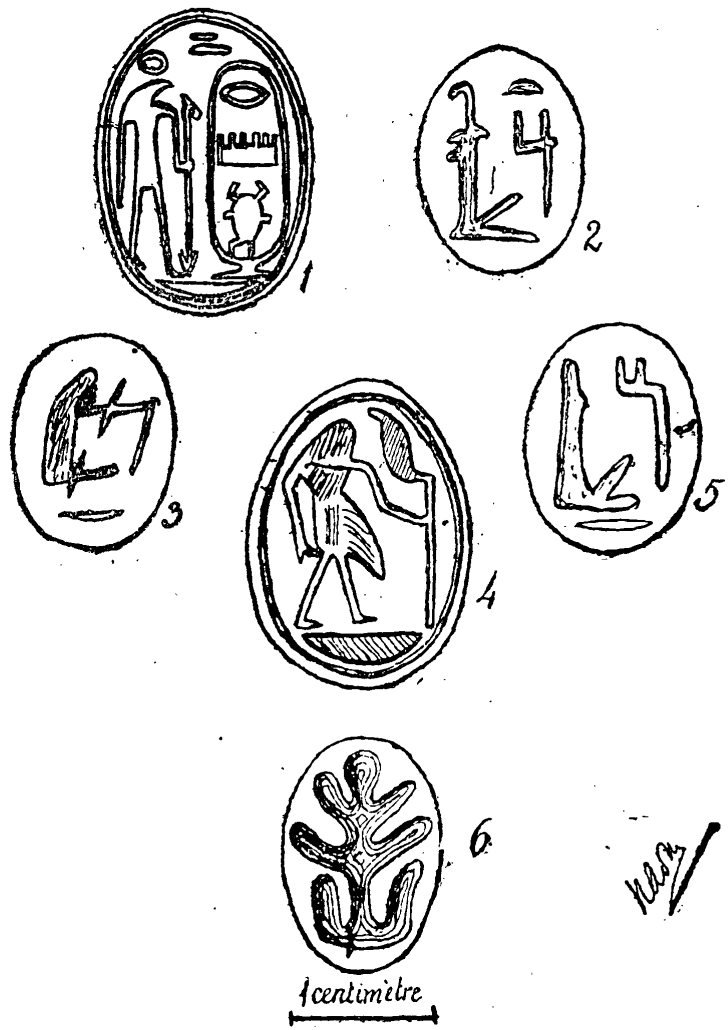

IV.-Scarabæi from Tell Zakarîya (1-2) and Tell es-Sâfi (3-6).

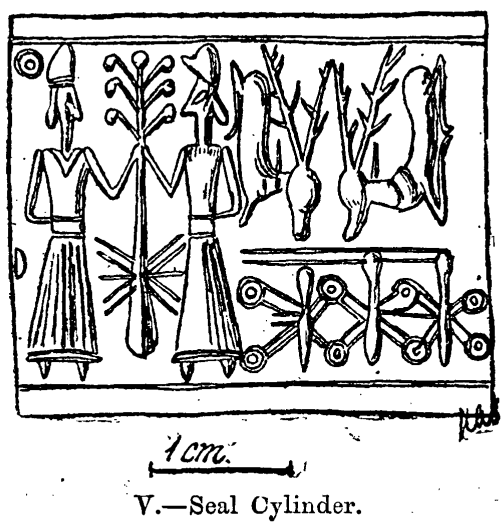


the only discoveries. The scarabs (Cut IV) 3 to 6 were all found at a depth of about 8 feet; 3 is of green jade, 5 and 6 are of bluish-green paste, 4 is slate. Nos. 1 and 2 were found at Zakarîya. No. 1 is of bone, and includes the cartouche of Thothmes III; No. 2, on which appear the characters found on 3 and 5 , is of paste. The cylinder (Cut V) shows stags couchant, back to back, and a tree, on each side of which is a male figure grasping the trunk.

So few were the results from this large clearance that we decided on another method for testing the field to the east. This field occupies a position almost in the centre of the ancient town, at a point about equi-distant from the east and west walls. Even had the Tell been unencumbered this would have been a point to be chosen for digging. Here we sank a series of shafts, 12 feet square and 16 feet apart, in three lines, each including four shafts, except the western line, on which there were but three, making 11 in all. These shafts were sufficiently large and sufficiently near together to make it extremely improbable that we should miss any important building. The idea was that if any such building were struck it would appear in more than one shaft, and we could then extend our digging to the spaces left between the shafts; or if a stratum of tablets appeared we could easily follow it in the same way. We thus hoped practically to exhaust the possibilities of an area 68 feet by 96 feet, which was the maximum area that could be excavated in this field, making allowance for space for depositing the earth against the enclosing cactus hedge. Rock was found at an average depth of 19 feet. Making the proper allowance for batter, we thus carefully examined over 25,000 cubic feet of soil, or about one-fifth the quantity which would have been excavated had we cleared out the whole area to the rock. The results were even more unsatisfactory than those from the western field. A few rude walls, generally of uncoursed rubble, were found at various depths, but with the exception of one late wall immediately under the surface, these were not found to extend from shaft to shaft. Signs of mud-brick walls and a rude pavement also appeared. Almost all the pottery was in fragments. The soil had been 
much disturbed in quite recent times, as a modern Arab coin was found at a depth of 10 feet, and many signs of filled-up pits appeared. To a depth ranging from 6 to 8 feet there was much Arab pottery intermingled with older styles. The peculiar Jewish styles were not in much evidence, the wall being chiefly pre-Israelite, including a stratum on the rock of the earliest types. In this stratum were found the extraordinarily thin flint knives and the thick scrapers for skinning animals, characteristic of the lowest city at Tell el-Hesy.

The buried jar, containing smaller vessels, has been mentioned with other groups described in the Tell Zakarîya report. These were all of the later pre-Israelite type. Up to the present season the earliest examples of buried vessels belonged to dates no earlier than the Phoenician period. However, 2 feet below the group just mentioned was found a very large jar, 33 inches high, showing some of the characteristics of the ware called by Petrie "Amorite," which antedates the Phoenician ware: beautifully curved neck, shoulder with cable moulding, disc base, and comb-facing, formed by an instrument with very wide spaces between the teeth. It stood upright, was empty, and was covered by a fragment of a dish, also of "Amorite" type showing the finer form of comb-facing.

So discouraging were the results from this field, which; by its position, appears to indicate an important part of the ancient city; and was proved by the pottery to represent a series of occupations from the very earliest times, that we decided it would not be wise to dig further in the remaining, or eastern field, in which we had already sunk three shafts; or to test two small fields, which represent the rest of theavailable space between the cemetery and the modern village. Neither did it seem worth while to return to the north-east plateau, where we had made a large clearance, and where the only important result had been the discovery of the supposed temple. In other words, the spaces available for excavation at Tell es-Sâfi had been sufficiently tested. The question now arises, from which part of the Tell came the statuettes, pottery masks, figures, and other interesting objects found in the rubbish heap? Apart from a 
few small stone fragments, from one of the 11 shafts just described, fragments which may possibly be the legs of small figures, nothing resembling these statuettes has been dug up. The objects from the rubbish heap appear to indicate a civilisation superior to anything suggested by the constructions we have excavated. We are obliged to conclude that the important portions of the city lie under the southern cemetery, which immediately covers the ruins of Blanche Garde (itself probably superposed on the ancient Acropolis) and under the modern village. In the courtyards of the houses and lying loose in the streets we observed several architectural fragments. Especially

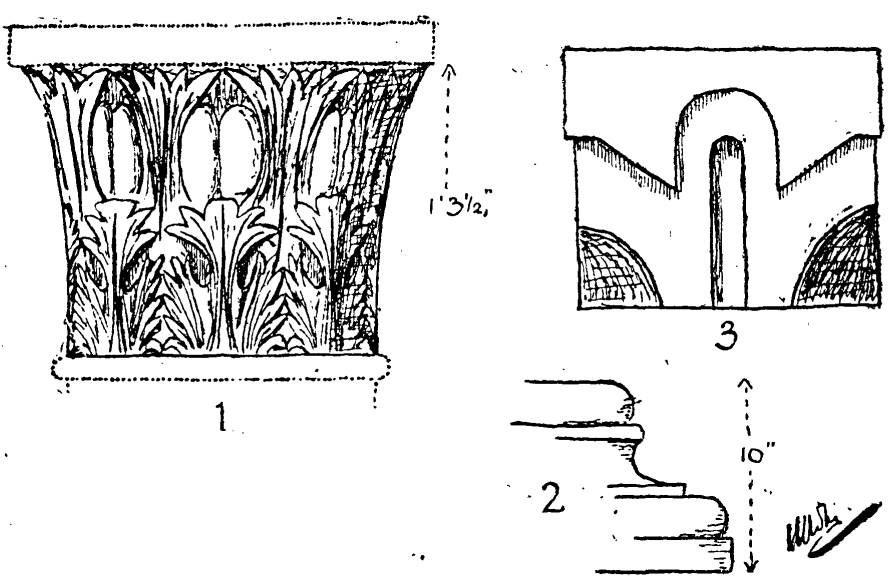

VI.-Architectural Fragments found in the Village of Tell es-Sâfi.

to be noticed are a debased Corinthian capital (No. 1 in Cut VI), two Attic bases of common type (No. 2), a fragment of a marble column with filleted flutings, and a rather early Romanesque capital (No. 3). A later Roman capital, founded on the Corinthian type, and showing the eight-pointed cross of the Knights of St. John in a circle just under the abacus, is lying beside the Wely on the north-east plateau.

On the plan of Tell es-Sâfi, north of the large cemetery, may be seen the mark $x$. This indicates the ruins of a tower, cropping out from the surface, at an angle of the field where we sank the 11 shafts. This was visible at the time of my visit 
to the place in 1891. In describing the city wall traced by us, I stated on p. 195 of the July Quarterly: "At $b$ five courses crop up above the surface, and this is probably the part seen by Dr. Petrie, and rightly taken by him to be part of the ancient rampart." My report was written under great pressure, while the work was going at full speed, and I must be pardoned an inaccuracy. .Petrie's note of the masonry seen by him is as follows (see his "Tell el-Hesy," p. 62) :- “Tell es-Sâfi : Walling of shallow drafted blocks with flat faces, long-stroke dressing." "This (the long-stroke dressing) is done with an edge or point, without showing any breadth of cut; the strokes are somewhat curved and in groups of parallel cuts. . . . . It is the dressing of the wall at Tell es-Sâfi ; this being surrounded by Amorite or early Jewish pottery .... is probably the old Philistine fortress of Gath" (p. 36).

As the wall at $b$ has evidently been exposed for years, and as we had proved it to be part of the ancient rampart, whereas the tower at $x$ appeared to me clearly to belong to an enclosure about the fortress of Blanche-Garde, I took it for granted that it was the former which was identified by Petrie with the city wall. However, a comparison of the masonry at both places with his description shows that the walling seen by him was the one at $x$. At $b$ the stones all have rough faces and are pock-marked. The tower at $x$ has been robbed of its facing stones, but two, though dislodged, have not been removed; and they correspond to Petrie's description, showing a shallowdrafted face and long-stroke picking. As stated above, the remains of the tower project from the corner of the central field, the ruins rising some 4 feet above the surface. We found it trenched about on three sides; as the upper facing stones have been removed we sank a shaft at the north-east angle, finding two courses of plain-faced stones, 16 and 18 inches in height respectively, the lower being a footing resting on foundation work of rude, unfaced rubble. The stones are roughly dressed with the comb-pick. Owing to its ruined condition, the dimensions of the tower could not be absolutely ascertained, but the trenches dug for removing the facing-stones permitted us to gauge the extent of the face at 25 feet, which 
must be correct within a foot or two. In this same way the sides were measured to the point where they run under the cemetery at about 21 feet. Along the face we found traces of a gate, 10 feet wide, i.e., a door-socket with jamb, rude sill, and signs of a second jamb. In a shaft sunk a few feet from the corner of the tower rock was found at 20 feet below the surface. The level of the sill is practically that of the adjacent part of the field; and 7 feet above the top of the foundation work below the footing found in the shaft at the angle. We thus have two limits between which the ground-level at the period of the tower must have lain, and for the extent of accumulation above the rock at the same period. If the door-sill indicates this ground-level, then when the tower was erected the field must have had its present level. In other words, on this hypothesis the tower represents the latest construction at this point. If the rude foundation work represents the ground-level of the tower, then we must assume a flight of steps leading down from the gate to a depth of 7 feet. It was impossible to test this theory without removing a dense cactus hedge-an impracticable task. Militating against it is the fact that the two courses found above the rubble are roughly dressed, have no drafts, and were hence probably always under ground. Even on this theory of a lower ground-level we must assime an accumulation above the rock of 13 feet of débris; hence in no case can this building be relegated to the earliest period. Unfortunately we had only two examples of the upper facingstones to study, and only one of these is whole. This measures 20 inches high by 37 long, the drafts are 2.75 inches in width. It is a corner stone. The face-dressing is that described above, but the rough inner surfaces show marks of the comb-pick. No mason's marks were found, nor signs of the unmistakable fine diagonal chiselling of the Crusaders. Mortar is found in the rough core of the wall, as well as clinging to the inner sides of the dislodged stones.

Notwithstanding the absence of peculiar Crusading marks we relegate this tower to the Crusading period for the following reasons:-(1) It occupies a position to which Blanche-Garde probably extended; (2) the door-sill probably indicates its 
ground-level, which is the same as that of the present surface of the field, showing that there has been no accumulation of débris since the tower was built. It is a matter for regret that the only building found at Tell es-Sâfi, showing well-dressed stones, could not be thoroughly examined, as all but a small part of it is under the cemetery, and as this small part has been molested.

Just outside the ancient city wall is a field east of the north-east plateau and at a considerably lower level. This field is flat, and we thought it might represent an extra-mural occupation, or possibly a cemetery. A few shafts proved the former theory to be correct, pottery being found to the rock. As this occurs at a maximum depth of 7 feet below the surface the occupation must have been slight. Cropping out from the

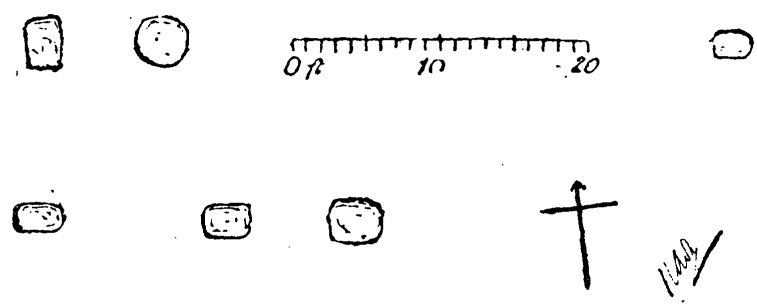

VII.-Remains of Alignments, Tell es-Sâf.

surface was found a roughly circular stone, and a scraping of the ground revealed five others, forming two lines running almost directly east and west. The largest is 41 inches in diameter. Careful trenching failed to reveal any others. These stones appear to be parts of two parallel alignments (Cut VII).

No gate has been found in the city wall. From the position of the city it appears likely that the main entrance was either from the south, leading directly into the Acropolis, or on the line of the modern approach to the village at the point $\alpha$, where a bit of the old wall is exposed. As at the latter point rock is found almost immediately under the surface, and the wall utterly gone north of the point $\alpha$, there was no hope of finding a gate. Mr. Macalister observed a road 16 to 18 feet broad; cut in the rock ascending the hill from the west and 
striking the $c o l$ at a point south of the Wely. At this point it seems to turn north, as signs' of a causeway appear leading towards the Tell. At a point somewhat east of the spot where this road should strike the city wall we sank a shaft. The lower part of the wall here consists of stone, the upper of mudbrick. Fallen brick was found to a considerable depth in front of the masonry. We deepened the shaft about 3 feet below the line where the mud-brick ceased, as this line indicated the minimum depth at which the door-sill should be found, and drove a tunnel west. As the tunnel was over 4 feet high, it was impossible that the door-sill should be above the level of its top, and it seemed unlikely that we should fail to strike the jamb of the gate, on the supposition that the sill was below the bottom of the tunnel. After tunnelling some 50 feet, operations were suspended owing to objections made by the Fellahîn to our tunnelling in the vicinity of the cemetery, as they utterly failed to see that between the tunnel and cemetery there existed a wall 10 feet thick! So once more were our plans frustrated by the practical difficulties existing at Tell es-Sâfi.

Since September 7th, when we arrived at Zakarîya after our summer's break, our camp has been pitched at four places. The first was under the olive trees near the well. The villagers gave us a hearty welcome, and prepared several feasts in our honour. At first we greatly suffered from the heat. On our return to Tell es-Sâfi we used the old camping ground until the approaching storms forced us to change the camp to a more sheltered position at the east of the Tell. Here we remained till November 24th, when we moved to Tell ej-Judeideh. Our experiences of Tell es-Sâfi had not been very happy, and on that Friday came a crowning touch. The large jar, which not only represented the only important result from the 11 shafts on which we had expended so much toil, but which was the only large specimen of early pre-Israelite ware we have ever found almost entirely whole, had been hauled up 20 feet to the surface, and safely transported to the camp. A man was detailed to carry it to Tell ej-Judeideh. Fearing some accident on the way, we photographed it the day before leaving. And then the unexpected happened.. After the tents had been taken down, and when several camel-loads had gone 
off, a little girl perched on the hillside above the camp accidentally loosed a large stone, which came crashing down right on to the precious jar. Of course, it was dashed to pieces, but all the fragments were preserved and packed in a box.

In our week's work at Tell ej-Judeideh we have been tracing the fortifications, having found many towers, a gate, \&c. The accumulation of débris is not great, but the pottery shows some of the earliest types. On the surface we have picked up a fragment of a Royal jar-handle with the place-name gone, and a fragment of a scarab. The camp is pitched in a hollow, not far from the summit. Owing to the successful diplomacy of Showkat Effendi, the Imperial Commissioner, we have had no trouble with the landowners. We are about two miles from Beit Jibrîn, where we hope to do some work next season. On the whole, the health of the party has been good.

Tell EJ-Judeideh, December $4 t h, 1899$.

Corrigenda in Previous Reports.

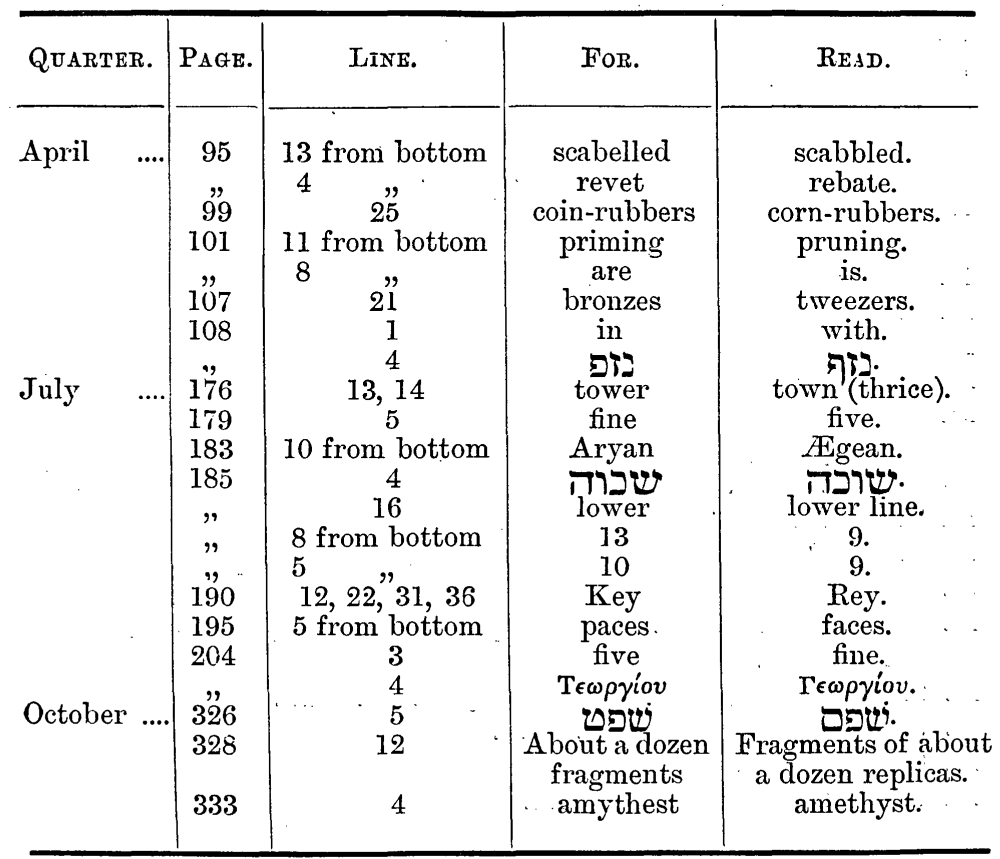




\section{LIST OF CASTS AND MOULDS.}

Received from Dr. Bliss; September, 1899.

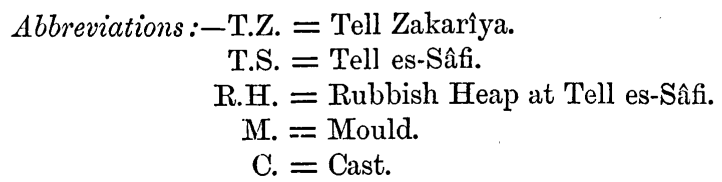

1. M. of weight (grammes 10), inscribed. White limestone. Sent before. T.Z.

2. M. of weight (grammes 9.45), inscribed. Dark red stone. Sent before. T.Z.

3. C. of No. 2. Note that scaling on sides of letters represents scaling on stone.

4. M. of red-stone seal. R.H.

5. M. of white agate seal. R.H.

6. M. of another white agate seal. R.H.

7. Wax impressions of markings on base of $4,5,6$, with markings on greenish-grey seal, also from R.H.

8. Wax impression of limestone (white) cylinder. T.S. Depth, 10 feet.

9. C. pottery slab. T.7.

10. C. pottery slab. T.Z.

11. C. jar-handle, Samaritan inscription. T.S. Not deep.

12. C. rude figure of woman and child. R.H.

13. C. green enamelled Ushabti fragment. R.H.

14. C. rude figure of pregnant woman. R.H.

15. C. figure with Semitic features. R.H.

16. C. Mycenæan (?) figure. R.H.

17. C. head of Silenus. R.H.

(The last three are hollow.)

18. C. rude horse and rider. R.H.

19. C. small mask, fragment. R.H.

20. C. of four fragments of slabs, Assyrian (?). R.H.

21. C. of three fragments of figures: one holding asp to breast, Cleopatra (?); one holding asp to thigh ; one of AEgis with Gorgon head. R.H.

22. C. jar-handle, with figure hunting a stag. R.H.

23. C. in red wax from stone mould of bell, showing clappers.

24. Ditto in plaster, clappers not shown. R.H.

25. C. rude archaic head. T.S. Depth about 20 feet, or level of bases o monoliths.

26. C. scarabs, 1-4, Plate VIII, July Quarterly. T.Z.

27. C. scarabs, 5-8, same plate. T.Z.

28. C. five scarabs. T.S.

29. C. five Babylonian gems. T.S. 
30. Painted casts of four Egyptian amulets ; one bone Phoenician figure ; one wooden object. T.S.

31. Wax impression of Hebrew inscription on jar-handle from R.H. Sent before. As sharp as possible, considering state of original.

32. Impression of bit of clay stamped with seal. R.H.

33. Two painted casts of grotesque heads in blue and yellow glass, with one obscene figure, s:me material. R.H.

34. C. small Greek head. R.H.

35. C. small archaic Greek head. R.H.

36. C. fragment of stone corbel with head, wearing lion's skin. R.H.

37. C. fragment of statuette. R.H.

38. C. rude head. T.S. Depth, 10 feet.

Sixty-four moulds and casts in all.

\section{THE . ROCK-CUTTINGS OF TELL ES-SÂFI.}

\section{By R, A. Stewart Macalister, M.A.}

THE extraordinary energy displayed by the ancient inhabitants of Tell Zakarîya in hollowing the hill that bore their stronghold -an energy shared by their contemporaries at Atraba, Beit Jibrîn, and other places in the neighbourhood-arouses expecta-. tions of the existence at Tell es-Sâfi of works similar to those I have already described in the Quarterly Statement (1899, p. 25). This expectation is largely disappointed; the rock-cut chambers of Tell es-Sâfi have not nearly the interest of those at Zakarîya, and a detailed account of them would be of little value for. a scientific discussion of the subject as a whole. I hope to show, however, that the remains of ancient rock-working at. Tell es-Ŝafi are by no means devoid of interest or of importance, and therefore propose to devote the present paper to a consideration of the principal examples, dividing them into groups similar to those into which I classified the Zakarîya cuttings in the paper already referred to.

\section{Chambers.}

The chambers of Tell es-Sâfi are of small interest, and I shall therefore clear the ground by cursorily describing them first. Not reckoning about half a dozen small chambers 